\title{
REDESAIN LEMBAR AKTIVITAS MAHASISWA BERDASARKAN ANALISIS KESULITAN MAHASISWA PADA KONSEP RANGKAIAN LISTRIK ARUS SEARAH PADA PERKULIAHAN FISIKA DASAR
}

\author{
Duden Saepuzaman', Syakti Perdana Sriyansyah ${ }^{2}$ dan Saeful Karim ${ }^{3}$ \\ ${ }^{1}$ Departemen Pendidikan Fisika, FPMIPA, Universitas Pendidikan Indonesia, \\ Jl. Dr. Setiabudhi No. 229, Bandung 40154 \\ ${ }^{2}$ Departemen Pendidikan Fiska, Sekolah Pascasarjana, Universitas Pendidikan Indonesia, \\ Jl. Dr. Setiabudhi No. 229, Bandung 40154
}

\section{E-mail: dsaepuzaman@upi.edu}

\begin{abstract}
ABSTRAK
Penelitian ini difokuskan pada redesain Lembar Aktivitas Mahasiswa (LAM) pada materi rangkaian listrik arus searah di perkuliahan Fisika Dasar. Redesain yang dimaksud adalah mendesain kembali LAM yang sudah diimplementasikan berdasarkan analisis kesulitan konseptual mahasiswa. Data kesulitan mahasiswa dianalisis dari lembar jawaban mahasiswa pada saat tes tertulis. Selain didasarkan pada upaya peningkatan pemahaman konsep mahasiswa, penelitian ini juga diharapkan dapat menghasilkan LAM yang standar yang bisa digunakan dalam perkuliahan Fisika Dasar khususnya untuk materi rangkaian listrik arus searah. Metode yang digunakan adalah metode deskriptif yang bertujuan untuk mengidentifikasi kesulitan mahasiswa sebagai dasar redesain LAM. Subjek yang terlibat dalam penelitian ini adalah mahasiswa prodi pendidikan Fisika semester III tahun akademik (TA) 2014/2015 sebanyak 41 mahasiswa dan mahasiswa TA 2015/2016 sebanyak 43. Instumen tes yang digunakan dalam penelitian berbentuk multiple choice yang diadaptasi dari Determining and Interpreting Resistive Electric Circuits Concepts Test Version 1.0 (DIRECT). Analisis jawaban mahasiswa TA 2014/2015 pada tes tertulis menunjukkan beberapa kesulitan konseptual mahasiswa sebagai berikut. Pertama, mengidentifikasi pengaruh besarnya hambatan (penambahan atau pengurangan hambatan) terhadap arus yang mengalir dalam rangkaian gabungan (seri-paralel) dan pada komponen listrik (lampu). Kedua, mengidentifikasi pengaruh penambahan hambatan yang dipasang seri terhadap arus dan tegangan atau nyala lampu. Ketiga,mengidentifikasi pengaruh penambahan hambatan yang diapasang paralel terhadap arus tegangan dan hambatan total. Keempat, membandingkan kuat arus yang melalui resistor (atau suatu titik dalam rangkaian) yang disusun paralel. Temuan ini menjadi dasar meredesain LAM. LAM yang sudah diredesain diujicoba kembali pada mahasiswa TA 2015/2016. Hasil dari implementasi redesain ini menunjukkan ada pengurangan kesulitan mahasiswa pada konsep rangkaian listrik arus searah.
\end{abstract}

Kata kunci: Analisis Kesulitan, Rangkaian Listrik Arus Searah, Redesain Lembar Aktivitas Mahasiswa

\begin{abstract}
This research focused on redesign of Student Activity Sheet (LAM) on direct current electric circuit in Basic Physics lecture. The intended redesign is a LAM redesign that has been implemented based on a student conceptual difficulties analysis. Student difficulties data were analyzed from the student's answer sheet at the time of written test. Besides based on efforts to improve students' concept understanding, this research is also expected to produce standard LAM which can be used in Basic Physics lecture especially for direct current electric circuit. The method used is descriptive method that aims to identify student difficulties as the basis for redesigning LAM. Subjects involved in this study are students of Physics education program semester III academic year (TA) 2014/2015 as many as 41 students and students FY 2015/2016 as many as 43. Instument test used in research form multiple choice which is adapted from Determining and Interpreting Resistive Electric Circuits Concepts Test Version 1.0 (DIRECT). Analysis of student responses FY 2014/2015 on a written test shows some student conceptual difficulties as follows. First, identify the effect of the magnitude of the resistance (addition or decrease in resistance) to the current flowing in the series (parallel-series) and in the electrical component (lamp). Second, identify the effect of adding a series mounted resistance to the current and voltage or flame of the lamp. Third, identify the effect of the
\end{abstract}


addition of barriers that are paralleled to the voltage current and total resistance. Fourth, compare the strength of the current through the resistor (or a point in the circuit) arranged in parallel. These findings serve as the basis for LAM redesign. The redesigned LAM is re-tested on FY 2015/2016 students. The result of this redesign implementation shows there is a reduction of student's difficulty on the concept of direct current electric circuit.

Keywords: Difficult Analysis, Current Circuit, Redesign Student Activity Sheet

Received: 14 Desember 2018 ; Accepted: 1 Februari 2019; Published: 4 Februari 2019 


\section{PENDAHULUAN}

Peningkatan kualitas pendidikan merupakan tanggung jawab semua pihak yang terlibat dalam dunia pendidikan, termasuk peran perguruan tinggi. Perguruan tinggi memegang peranan penting dalam mencetak lulusan yang mempunyai kompetensi unggul dan kompetitif sesuai dengan bidangnya. Untuk perguruan tinggi yang berperan sebagai Lembaga Pendidikan Tenaga Kependidikan (LPTK) maka kompetensi calon guru yang dihasilkan harus bersesuaian dengan Standar Kualifikasi Akademik dan Kompetensi Guru. Sebagai contoh, kompetensi calon guru Fisika mengacu pada Standar Kualifikasi Akademik dan Kompetensi Guru dalam Permendiknas RI nomor 16 tahun 2007 secara eksplisit menjelaskan bahwa salah satu kompetensi yang harus dimiliki adalah memahami konsep, hukum, dan teori Fisika serta penerapannya secara fleksibel. Untuk merealisasikan tujuan tersebut, maka LPTK adalah lembaga yang bertugas untuk memastikan bahwa calon guru Fisika telah memiliki kompetensi itu. Adapun aktivitas riil dalam upaya peningkatan pemahaman konsep calon guru adalah melalui pembelajaran atau perkuliahan di kelas (Karim, et al., 2015). Secara operasional kompetensi yang diharapkan dalam perkuliahan di kelas dituangkan dalam bentuk capaian pembelajaran (Learning Outcome) mata kuliah. Penelitian ini akan difokuskan pada perkuliahan Fisika Dasar II di salah satu LPTK di Kota Bandung. Implementasi perkuliahan di kelas mengacu pada capaian pembelajaran mata kuliah Fisika Dasar II yaitu menguasai konsep, prinsip, hukum dan teori fisika.

Dalam setiap perkuliahan, baik dosen, mahasiswa maupun semua pihak senantiasa mengharapkan agar capaian pembelajaran mata kuliah yang telah ditetapkan dapat tercapai. Berdasarkan hasil diskusi tim pengampu mata kuliah Fisika Dasar II di satu LPTK di Kota Bandung, diperoleh bahwa Dosen terkadang telah merasa total dalam membelajarkan mahasiswa, tetapi jika ditinjau dari hasil tes atau ujian, banyak mahasiswa yang mengalami kesulitan konseptual sehingga tidak dapat mencapai hasil belajar yang diharapkan. Hal tersebut senada dengan laporan penelitian yang menunjukkan bahwa bahkan setelah menyelesaikan perkuliahan, mahasiswa masih mengalami kesulitan konseptual yang mendasar terutama dalam pokok bahasan mekanika (Mc Dermott, 1984; 2001). Sekalipun juga telah menyelesaikan banyak soal yang terdapat dalam buku Fisika selama perkuliahan, tetapi masih saja tidak dapat mengatasi kesulitan konseptual yang dihadapi mahasiswa (Kim dan Pak, 2002). Keadaan ini dapat dipahami karena mahasiswa sering tidak fokus pada keterampilan yang mesti mereka kuasai agar dapat menyelesaikan soal secara fleksibel dan reliabel dalam berbagai konteks (seperti menginterpretasi dan membangun representasi fisis dari sebuah soal), melainkan hanya menginginkan bagaimana cara cepat memperoleh jawaban (Johnson, 2001).

Kesulitan konseptual yang dihadapi mahasiswa dari berbagai belahan dunia telah banyak didokumentasikan dalam laporan penelitian pendidikan Fisika (Halloun dan Hestenes, 1985; Van Heuvelen, 1991a McDermott dan Shaffer, 1992 ; McDermott dan Redish, 1999; Hsu et al., 2004). Banyak faktor yang mempengaruhi kurang optimalnya pemahaman konseptual yang dicapai mahasiswa calon guru Fisika, salah satunya adalah proses pembelajaran (Kahyaoglu, 2007). Meskipun banyak hasil penelitian pendidikan Fisika tentang strategi pembelajaran yang berhasil meningkatkan pemahaman konsep mahasiswa (Van Heuvelen, 1991a; 1991b; Heller et al., 1992a; Hollabaugh; 1992b; McDermott, 1997; 2001; Hellerdan Crouch dan Mazur, 2001; Mc Demort 2014), namun penggunaanya pada populasi mahasiswa yang berbeda bisa jadi tidak selalu memberikan hasil yang optimal disebabkan oleh perbedaan karakteristik (seperti perbedaan kemampuan penalaran, gaya belajar, pengetahuan awal dan kemampuan matematis) mahasiswa (Meltzer, 2002; Coletta dan Phillips, 2005). 
Berdasarkan hasil tes tertulis di perkuliahan Fisika Dasar diketahui bahwa materi rangkaian listrik arus searah merupakan salah satu materi yang tingkat kesulitan konseptual mahasiswanya cukup tinggi. Salah satu upaya untuk mengetahui secara spesifik kesulitan konseptual mahasiswa adalah dengan menganalisis jawaban mahasiswa. Secara umum, beberapa temuan terkait kesulitan konseptual mahasiswa pada materi rangkaian listrik arus searah sebagai berikut. Analisis jawaban mahasiswa pada tes tertulis menunjukkan beberapa kesulitan konseptual mahasiswa sebagai berikut. Pertama, Menganalisis pengaruh arus dan tegangan pada suatu hambatan setelah ditambahkan hambatan yang dipasang paralel. Kedua, Menganalisis arus dan tegangan suatu hambatan setelah ditambahkan hambatan lain yang dipasang seri. Ketiga, Menjelaskan pengaruh hambatan yang diperbesar terhadap arus yang mengalir pada komponen listrik yang dipasang seri. Keempat, Kesulitan dalam hal mengurutkan besar arus di beberapa titik dalam rangkaian paralel. Kelima, Kesulitan dalam menjelaskan karakteristik rangkaian. Keenam, penentuan penjumlahan atau pengurangan potensial menggunakan hukum Kirchoff masih keliru.

Penelitian ini difokuskan pada upaya redesain LAM materi Rangkaian Listrik Arus Searah berdasarkan analisis kesulitan konseptual mahasiswa

\section{METODE PENELITIAN}

Metode yang digunakan adalah metode deskriptif yang bertujuan untuk menganalisis kesulitan mahasiswa dan meredesain Lembar Aktivitas Mahasiswa (LAM) perkuliahan Fisika Dasar II di salah satu LPTK di Bandung. Subjek yang terlibat dalam penelitian ini adalah mahasiswa prodi pendidikan Fisika semester III tahun akademik (TA) 2014/2015 sebanyak 41 mahasiswa dan mahasiswa TA 2015/2016 sebanyak 43. Analisis kesulitan mahasiswa diperoleh dari jawaban mahasiswa pada tes tertulis konsep rangkaian listrik arus searah. Instrumen tes berbentuk multiple choice berjumlah 24 item yang sebagian diadaptasi dari Determining and Interpreting Resistive Electric Circuits Concepts Test Version 1.0 (DIRECT). Secara umum, instrumen tes rangkaian listrik arus searah meliputi subkonsep hukum ohm, susunan hambatan seri- parallel dan hukum Kirchoff. Temuan kesulitan mahasiswa pada tes tertulis dijadikan dasar dalam mendesain LAM. LAM ini bersisikan pertanyaan konseptual arahan secara sistematis sesuai dengan temuan penelitian, jenjang berpikir dan urutan konstruksi konsep Fisika.

\section{HASIL DAN PEMBAHASAN}

\section{Analisis Kesulitan Mahasiswa pada konsep rangkaian listrik arus searah.}

Pada bagian ini akan dijelaskan beberapa temuan kesulitan konseptual mahasiswa dalam menjawab tes rangkaian listrik arus searah. Kesulitan mahasiswa diidentifikasi dari pencapaian hasil postest mahasiswa TA 2015/2016 secara umum disajikan dalam tabel 1.

Tabel 1. Persentasi Mahasiswa yang Menjawab Benar Instrumen Tes Rangkaian listrik Arus Searah

\begin{tabular}{lccc}
\hline \multicolumn{1}{c}{ Indikator item soal } & $\begin{array}{c}\text { No. Item } \\
\text { Soal }\end{array}$ & $\begin{array}{c}\text { Pretest } \\
\text { (\%) }\end{array}$ & $\begin{array}{c}\text { Postest } \\
\text { (\%) }\end{array}$ \\
\hline Hukum Ohm & & & \\
\hline $\begin{array}{l}\text { HO 1. Membandingkan nilai hambatan beberapa penghantar berdasarkan } \\
\text { data hasil eksperimen }\end{array}$ & 1 & 75,61 & 92,68 \\
\hline $\begin{array}{l}\text { HO 2. Menentukan kuat arus yang mengalir pada rangkaian listrik jika } \\
\text { hambatan penghantar diubah }\end{array}$ & 2 & 68,29 & 78,05 \\
\hline $\begin{array}{l}\text { HO 3. Mempertimbangkan cara untuk meningkatkan arus yang mengalir } \\
\text { dalam rangkaian }\end{array}$ & 3 & 48,78 & 70,73 \\
\hline
\end{tabular}


JoTaLP: Journal of Teaching and Learning Physics 4, 1 (2019): 34-42

Website: http://journal.uinsgd.ac.id/index.php/jtlp/index ISSN 2580-3107 (online) ISSN 2528-5505 (print)

\begin{tabular}{lccc}
\hline $\begin{array}{l}\text { Karakteristik diagram rangkaian, hambatan, arus dan tegangan } \\
\text { berbagai rangkaian listrik (seri, paralel , gabungan ) }\end{array}$ & & & \\
\hline $\begin{array}{l}\text { SP.1. Menggambarkan skema rangkaian listrik yang merepresentasikan } \\
\text { rangkaian listrik sebenarnya atau yang sama dari beberapa jenis rangkaian }\end{array}$ & 4,5 & 68,29 & 85,37 \\
\hline $\begin{array}{l}\text { SP 2. Mengidentifikasi pengaruh penambahan hambatan yang dipasang seri } \\
\text { terhadap arus dan tegangan atau nyala lampu }\end{array}$ & 6,7 & 31,71 & $43,90^{*} 2$ \\
\hline $\begin{array}{l}\text { SP 3. Menunjukkan karakteristik besar arus yang mengalir dalam rangkaian } \\
\text { seri }\end{array}$ & 10,11 & 70,73 & 92,68 \\
\hline SP 4. Membandingkan beda potensial antar ujung resistor yang disusun seri & 12,13 & 73,17 & 97,56 \\
\hline $\begin{array}{l}\text { SP 5. Mengidentifikasi pengaruh penambahan hambatan yang dipasang } \\
\text { paralel terhadap arus tegangan dan hambatan total }\end{array}$ & $8,17,18$ & 36,59 & $53,66^{* 3}$ \\
\hline $\begin{array}{l}\text { SP 6. Membandingkan kuat arus yang melalui resistor (atau suatu titik } \\
\text { dalam rangkaian) yang disusun paralel }\end{array}$ & $9,14,15$, & 51,22 & $54,34^{* 4}$ \\
\hline $\begin{array}{l}\text { SP 7. Membandingkan beda potensial antar ujung resistor yang disusun } \\
\text { paralel }\end{array}$ & 16,20 & 53,66 & 65,85 \\
\hline $\begin{array}{l}\text { SP 8. Menganalisis besar hambatan total suatu rangkaian setelah } \\
\text { penambahan hambatan pada rangkaian gabungan seri-paralel }\end{array}$ & 18 & 46,34 & 80,49 \\
\hline $\begin{array}{l}\text { SP 9. Mengidentifikasi besar dan arah arus yang mengalir dalam rangkaian } \\
\text { jika dihubungkan antara dua titik dalam rangkaian }\end{array}$ & 21 & 29,27 & 70,73 \\
\hline $\begin{array}{l}\text { SP 10. Mengidentifikasi pengaruh besarnya hambatan ( penambahan atau } \\
\text { pengurangan hambatan) terhadap arus yang mengalir dalam rangkaian } \\
\text { gabungan (seri-paralel) dan pada komponen listrik (lampu) }\end{array}$ & 23,24 & 24,39 & $41,46^{* 1}$ \\
\hline Hukum Kirchoff & & & \\
\hline $\begin{array}{l}\text { HK. Memformulasikan keberlakuan hukum I Kirchoff dengan arah arus } \\
\text { listrik untuk masing-masing percabangan telah diketahui }\end{array}$ & 22 & 39,02 & 90,24 \\
\hline Rata-rata & & 51,22 & 72,13 \\
\hline
\end{tabular}

Berdasarkan data pada tabel diperoleh bahwa terdapat beberapa mahasiswa yang pencapaian hasil belajarnya masih dibawah $60 \%$. Secara khusus, analisis terhadap kesulitan mahasiswa untuk 3 item soal dijelaskan sebagai berikut.

Pertama, mengidentifikasi pengaruh besarnya hambatan (penambahan atau pengurangan hambatan) terhadap arus yang mengalir dalam rangkaian gabungan (seri-paralel) dan pada komponen listrik (lampu). Sebagai contoh soal soal no 23 seperti disajikan pada gambar 1 .

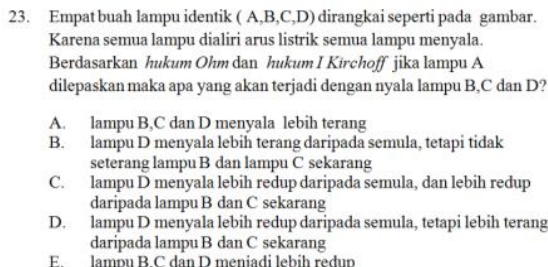

Gambar 1. Item soal nomor 23
Hasil wawancara dengan beberapa mahasiswa ditemukan kesulitan/ kekeliruan mahasiswa sebagai berikut.

- Ketika lampu A dilepaskan, maka arus yang mengalir pasti akan semakin besar karena hambatannya mengecil. Sehingga arus yang mengalir dalam rangkaian menjadi lebih besar dan lampu semuanya akan menyala lebih terang sesuai dengan hukum ohm V=IR (padahal kondisi ini hanya berlaku jika rangkaiannya seri tidak berlaku umum )

- Ketika lampu A dilepaskan, karena lampu A disusun paralel maka hambatan totalnya menjadi lebih besar, maka arus yang mengalir pasti akan semakin kecil karena hambatannya membesar. Karena nyala lampu sangat dipengaruhi arus, maka lampu yang laiinya akan menjadi redup.

Konsepsi mahasiswa yang keliru ini diduga karena anggapan bahwa hukum Ohm, V=IR berlaku secara umum untuk semua kasus dalam rangkaian. Padahal, untuk rangkaian yang 
berbeda kita harus menganalisis rangkaian secara keseluruhan dan untuk masing-masing lampu.

Kedua, mengidentifikasi pengaruh penambahan hambatan yang dipasang seri terhadap arus dan tegangan atau nyala lampu yang direpresentasikan oleh soal nomor 6 dan nomor 7. Sebagai contoh soal nomor 6 yang disajikan pada gambar 2

6. Suatu rangkaian listrik terdiri dari satu buah resistor A yang dihubungkan dengan sebuah sumber tegangan. Jika pada rangkaian tersebut ditambahkan sebuah resistor B secara seri, maka bagaimana dengan arus dan tegangan pada resistor A setelah resistor B ditambahkan?

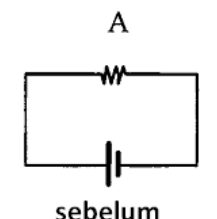
A. Arus dan tegangan meningkat
B. Arus dan tegangan menurun
C. Arus meningkat dan tegangan menurun
D. Arus menurun dan tegangan meningkat
E. Arus dan tegangan tetap

Gambar 2. Item soal nomor 6

Kekeliruan konsepsi mahasiswa terbesar dalam menjawab soal ini yaitu adanya konsepsi bahwa " besarnya arus pada rangkaian seri selalu sama “. Konsepsi ini nampaknya terus diyakini bahkan untuk kondisi yang berbeda (sebelum dan sesudah). Padahal kondisi arus sama pada rangkaian seri berlaku pada rangkaian yang sama. Analisis lanjutan menunjukkan bahwa mahasiswa tidak terbiasa dengan soal-soal yang menunjukkan dua kondisi yang berbeda atau berubah. Sebagai contoh, ada beberapa mahasiswa mempunyai konsepsi bahwa A akan mempunya arus lebih besar $B$, karena arus yang dihasilkan batere akan digunakan lebih banyak oleh A dan B hanya menerima sisa arus dari resistor A. Konsepsi ini jelas keliru karena arus dalam rangkaian seri sama.
Ketiga,mengidentifikasi pengaruh penambahan hambatan yang diapasang paralel terhadap arus tegangan dan hambatan total. Indikator ini diwakili oleh item soal no 8, 17 dan 18. Sebagai contoh soal nomor 8 seperti disajikan pada gambar 3.

8. Suatu rangkaian listrik terdiri dari satu buah resistor A yang dihubungkan dengan sebuah sumber tegangan. Jika pada rangkaian tersebut ditambahkan sebuah resistor B yang dipasang paralel dengan resistor A, maka bagaimanakah dengan arus dan tegangan pada resistor A setelah resistor B ditambahkan?
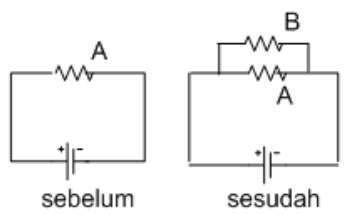
A. Arus dan tegangan meningkat
B. Arus dan tegangan menurun
C. Arus meningkat dan tegangan menurun
D. Arus menurun dan tegangan meningkat
E. Arus dan tegangan tetap

Gambar 3. Item soal nomor 8

Beberapa kekeliruan konsepsi mahasiswa untuk item soal nomor 8 sebagai berikut.

- Tidak mempertimbangkan perubahan arus total karena perubahan nilai resistor total. Sehingga besarnya arus pada resistor A langsung akan menurun karena arusnya terbagi di titik percabangan sebagai prinsip pembagian arus pada rangakain parallel.

- Beda potensial baterai terbagi sehingga besarnya tegangan pada resistor A berkurang menjadi setengah dari semula akibat sebagian beda potensial diberikan pada resistor $B$

Keempat, membandingkan kuat arus yang melalui resistor (atau suatu titik dalam rangkaian) yang disusun paralel yang diuji oleh 
item soal no 9, 14, 15 dan 19 . Sebagai contoh soal no 14 seperti disajikan pada gambar 4 .

14. Dua buah lampu identik disusun secara paralel dan dihubungkan dengan sebuah sumber tegangan seperti gambar dibawah ini. Urutan besarnya arus yang melalui titik 1, 2, 3, 4, 5 dan 6 mulai dari yang besar ke yang kecil adalah....

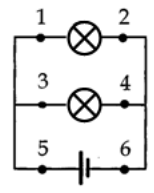
A. $\mathrm{I}_{5}, \mathrm{I}_{1}, \mathrm{I}_{3}, \mathrm{I}_{2}, \mathrm{I}_{4}, \mathrm{I}_{6}$
B. $\mathrm{I}_{5}, \mathrm{I}_{3}, \mathrm{I}_{1}, \mathrm{I}_{4}, \mathrm{I}_{2}, \mathrm{I}_{6}$
C. $\mathrm{I}_{5}=\mathrm{I}_{6}, \mathrm{I}_{3}=\mathrm{I}_{4}, \mathrm{I}_{1}=\mathrm{I}_{2}$
D. $\mathrm{I}_{5}=\mathrm{I}_{6}, \mathrm{I}_{1}=\mathrm{I}_{2}=\mathrm{I}_{3}=\mathrm{I}_{4}$
E. $\mathrm{I}_{1}=\mathrm{I}_{2}=\mathrm{I}_{3}=\mathrm{I}_{4}=\mathrm{I}_{5}=\mathrm{I}_{6}$

Gambar 4. Item soal nomor 14

Konsepsi dari beberapa mahasiswa menunjukkan adanya kekeliruan siswa pada penentuan arus di setiap titik. Beberapa siswa

Table 2. Redesain sampel Lembar Aktivitas Mahasiswa (LAM) Materi Rangkaian Listrik Arus Searah untuk Subkonsep Rangkaian Paralel

\begin{tabular}{|c|c|}
\hline LAM (sebelum redesain) & LAM (setelah redesain) \\
\hline $\begin{array}{l}\text { 1. Tiga buah hambatan listrik, masing-masing mempunyai nilai hambatan } \\
\mathrm{R}_{1}, \mathrm{R}_{2} \text {,dan } \mathrm{R}_{3} \text { dirangkaikan dengan baterai dengan beda potensial } \mathrm{V} \\
\text { seperti gambar rangkaian disamping. } \\
\text { a. Hambatan total ? } \\
\text { b. Arus total dan arus yang melalui masing-masing hambatan? } \\
\text { c. Beda potensial pada masing-masing hambatan ? } \\
\text { 2. Jika besamya beda potensial baterai pada } 6 \text { volt dan besarnya hambatan } \\
\text { masing-masing adalah } 2 \text { ohm, tentukan : } \\
\text { (i) hambatan total ? } \\
\text { (ii) besar arus yang melalui masing-masing hambatan? } \\
\text { (iii) besar beda potensial antar ujung masing-masing hambatan? }\end{array}$ & 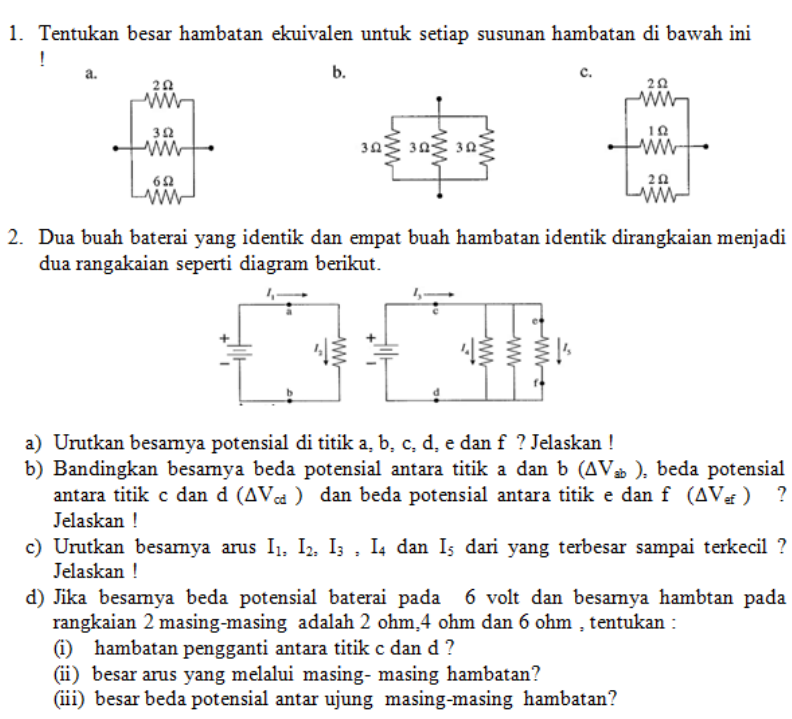 \\
\hline
\end{tabular}

beranggapan bahwa besarnya arus bergantung pada jalannya arus yang mengalir dalam rangkaian dengan awal aliran dari kutub positif batere dan berakhir di kutub negatif baterai. Besarnya arus akan terus mengalir sehingga bagian paling akhir paling kecil yaitu di bagian yang dekat dengan kutub negatif .

\section{Redesain Lembar Aktivitas Mahasiswa (LAM) Materi Rangkaian Listrik Arus Searah}

Berdasarkan analisis kesulitan konseptual mahasiswa pada konsep rangkaian listrik arus searah, maka dibuat redesain LAM yang dapat meminimalisir kesulitan konseptual yang dihadapi mahasiswa. Sebagai contoh untuk membantu kesulitan mahasiswa pada temuan 1 dan 4 sebelumnya disajikan dalam tabel 2 . 
Ujicoba LAM yang sudah diredesain dilakukan pada 43 mahasiswa prodi pendidikan Fisika semester III tahun akademik (TA) 2015/2016. Proses pembelajaran dengan menggunakan LAM yang diredesain lebih interaktif, karena mahasiswa dibimbing untuk menyelesaikan persoalan-persoalan dalam LAM. Keefektifan implementasi LAM yang diredesain diukur dengan instrumen tes yang sama yang diberikan setelah perkuliahan konsep rangkaian listrik arus searah selesai. Hasil uji instrumen tes dicapai dibandingkan dengan hasil uji tes sebelumnya disajikan dalam gambar 5 .

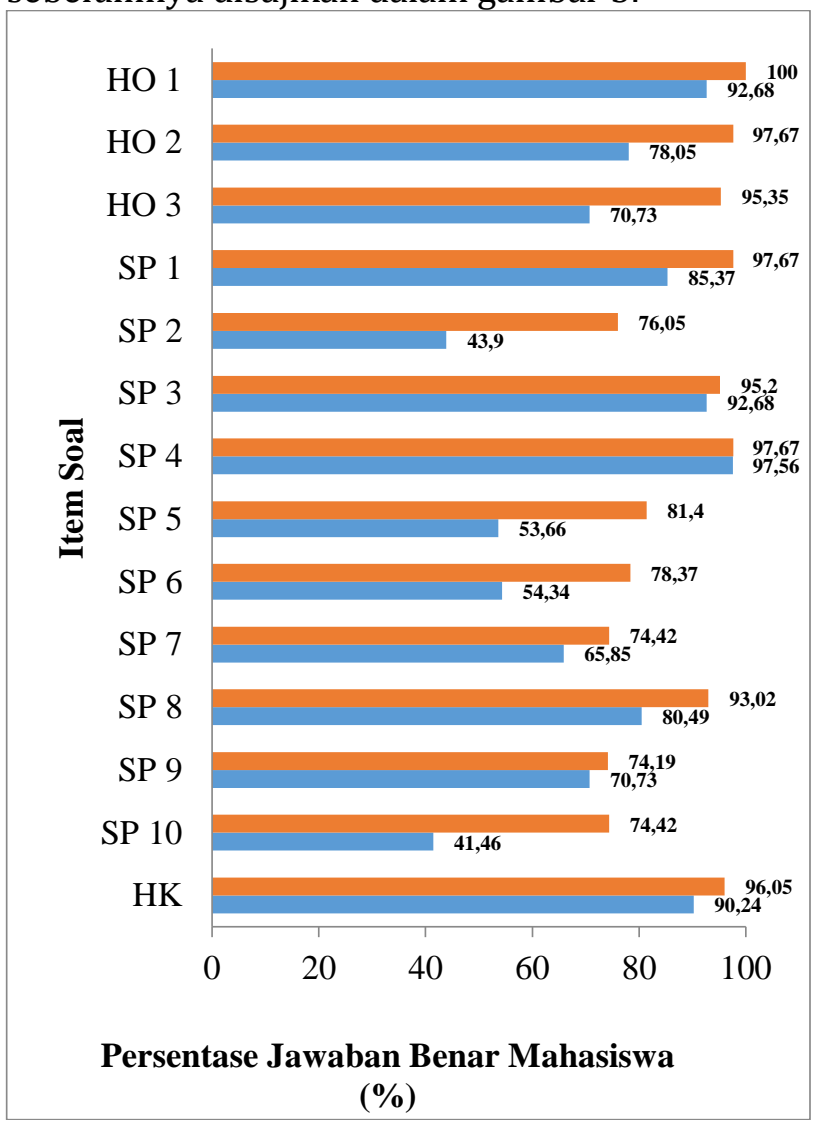

Keterangan :

$2014 / 2015$

$2015 / 2016$

Gambar 5. Perbandingan persentase Mahasiswa yang Menjawab Benar Tes Konsep Rangkaian Listrik Arus Searah Angkatan 2014/2015 dan angkatan 2015/2016

Gambar 5 memperlihatkan bahwa terdapat peningkatan persentase mahasiswa jawaban benar pada setiap item soal. Ini menunjukkan adanya peningkatan hasil belajar dari tahun akademik 2013/2014 dan 2014/2015 sampai tahun akademik 2015/2016. Peningkatan capaian ini tentu tidak terlepas dari peran LAM yang digunakan. Sebagai contoh, setelah implementasi LAM yang diredesain ini jumlah mahasiswa yang mengalami kesalahan konsepsi pada soal SP 10 bahwa "Ketika salah satu lampu dalam rangkaian dilepaskan, maka arus yang mengalir pasti akan semakin besar karena hambatannya mengecil. Sehingga arus yang mengalir dalam rangkaian menjadi lebih besar dan lampu lainnya akan menyala lebih terang sesuai dengan hukum ohm V=IR" . Pada tahun akademik 2014/2015 jumlah mahasiswa yang menjawab benar soal ini hanya $41,46 \%$. Sedangkan pada tahun akademik 2015/2016 menjadi $74,42 \%$. Implementasi LAM yang disajikan dalam bentuk pertanyaan konseptual arahan dengan menggunakan beragam representasi membuat mahasiswa menjadi lebih berpikir dan mempertimbangkan secara detail jawaban mereka. Selain itu, pembelajaran di kelas menjadi lebih aktif dan kaya dengan diskusi konseptual interaktif antar mahasiswa atau antara mahasiswa dengan dosen.

\section{KESIMPULAN}

Upaya untuk memperbaiki kualitas perkuliahan bisa dilakukan dengan menganalisis kesulitan konseptual mahasiswa. Sebagai contoh, dalam materi Fisika Dasar mahasiswa mengalami kesulitan konseptual pada materi rangkaian listrik arus searah. Temuan terkait kesulitankesulitan konseptual mahasiswa dijadikan dasar dalam pengembangan Lembar Aktivitas Mahasiswa (LAM). LAM awal yang diimplementasikan dipandang masih kurang dalam memberikan penguasaan konsep rangkaian listrik arus searah pada mahasiswa Fisika Dasar. Redesain LAM yang dibuat dan diimplementasikan ternyata mampu memfasilitasi mahasiswa dalam meningkatkan pencapaian penguasaan konsep. 


\section{DAFTAR PUSTAKA}

Coletta, V. P. dan Phillips, J. A. (2005). Interpreting FCI scores: Normalized gain, preinstruction scores, and scientific reasoning ability. Am. J. Phys.73(12). pp. 1172-1182.

Engelhardt, P. V., \& Beichner, R. J. (2004). Students' understanding of direct current resistive electrical circuits. American Journal of Physics, 72(1), 98-115.

Halloun, I.A., Hestenes, D. (1985). The initial knowledge state of college physics students. Am. J. Phys.53. pp 1043-1055.

Hsu, L., Brewe, E., Foster, T.M., Harper, K.A. (2004). Resource Letter RPS-1: Research in problem solving. Am. J. Phys. 72 (9). pp. 1147-1156.

Johnson, M. (2001).Facilitating high quality student practice in introductory physics.Am. J. Phys. 69 (7).pp. S2-S11.

Kahyaoglu, Z. T. (2007). Factors affecting physics achievement in Turkish High Schools. Tesis. Middle East Technical University, Ankara

Kim, E. dan Pak, S. (2002).Students do not overcome conceptual difficulties after solving 1000 traditional problems. Am. J. Phys. 70 (7). pp. 759-765.

McDermott, L. C. (1984). Research on conceptual understanding mechanics.Phys.Today37(7). pp. 24-32.

McDermott, L. C., Shaffer, P. S. (1992). Research as a guide for curriculum development: An example from introductory electricity. Part I: Investigation of student understanding. Am. J. Phys.60 (11), pp. 994-1003.

McDermott, L. C., Shaffer, P. S. and the Physics Education Group at the University of Washington.(2002a). "Tutorial in Introductory Physics". New Jersey: Prentice-Hall Inc.

McDermott, L. C., Shaffer, P. S. and the Physics Education Group at the University of Washington.(2002b). "Tutorial in Introductory Physics, Homework". New Jersey: Prentice-Hall Inc.
McDermott, L.C. (1997). Bridging the gap between teaching and learning: The role of research.The Changing Role of Physics Departments in Modern Universities: Proceedings of ICUPE, edited by E. F. Redish and J. S. Rigden. CP399. pp. 139165.

McDermott, L.C. (2013). Improving the teaching of science through discipline-based education research : An example from physics. Eur. J. Sci. Math. Ed.1(1). pp. 1-12.

McDermott, L.C. (2014). Melba Newell Phillips Medal Lecture 2013: Discipline-Based Education Research-A View From Physics. Am. J. Phys.82(8). pp. 729-741.

McDermott, L.C. and the Physics Education Group at the University of Washington (1996)."Physics by Inquiry”.New York:Jhon Wiley dan Sons. Inc.

McDermott. L. C. (2001). Oersted Medal Lecture 2001: "Physics Education Research - The key to student learning". Am. J. Phys. 69 (11). pp. 1127-1137.

McDermott. L. C., Redish, E. F. (1999). Resource Letter: PER-1: Physics Education Research. Am. J. Phys. 67 (9). pp. 755-767.

Meltzer, D. E. (2002). The relationship between mathematics preparation and conceptual learning gains in physics: A possible "hidden variable" in diagnostic pretest scores. Am. J. Phys.70(12). pp. 1259-1268.

Saepuzaman, D. (2017). Tutorial Pra-Kelas: Sebuah Strategi Pembelajaran Untuk Meningkatkan Pemahaman Konsep Pada Perkuliahan Fisika Dasar. Jurnal Pengajaran MIPA, 21(2).

Van Heuvelen, A. (1991a). Learning to think like a physicist: A review of research-based instructional strategies.Am. J. Phys.59(10). pp. 891-897.

Van Heuvelen, A. (1991b). Overview, Case Study Physics.Am. J. Phys.59(10). pp. 898-907 